\author{
Adetola, O. B, Odunlami, D, Fasanmi, S. A, Yinusa, G. O, Adedeji, I. A, Solaja, \\ M. O, Popoola D, Ogede S, Ogunbote O, \& Sunmola, B.
}

\title{
Waste to Wealth Perspective: Identifying Waste Potentials for Small Scale Business Development in Ogun State, Nigeria
}

\begin{abstract}
The paper addresses the possibility of wealth creation in the real sense of it beyond theoretical postulations, which abound from previous studies on waste in Nigeria. Among such previous studies referenced, majority did not delve into the real process of turning waste to wealth for the purpose of creating actual wealth. This study therefore intends to achieve actual wealth creation from waste by throwing entrepreneurial challenge to the indigenous talented and skillful individuals. The study discovered six 'waste' items, that is, maize husk, pure water nylon, banana stem, pineapple leaves, sisalina leaves and areca leaves that are convertible manually into new products such as maize-husk paper products; paving stones/slabs from pure water-nylon; banana stem, pineapple leaves and sisalina fibre for weaving products such as caps, bags, cloths, floor mats, table mats, decorations, and areca-leaves into -nut plates and spoons useful at parties, restaurants and bukas in Nigeria and Africa.
\end{abstract}

Keywords: waste, wealth, small scale, business development.

\section{Introduction}

Wastes, mostly regarded as unwanted and harmful materials, are produced as a result of man's interaction with nature in an unsustainable manner. The interaction conflicting becomes constant due to the increasing human needs and desire to satisfy endless wants which in turn makes waste management an indispensable task in achieving sustainable development. Wastes are not prime products - produced for the market, do not occur in normal commercial and utility circles but possess potential for further use in production, transformation or consumption (EIONET, 2009 cited in Abiti, 2013). Waste can be understood based on three cardinal processes - source, effect on humans/environment and the control which are appropriate to deal with it. In this study, reference is to the source and control of waste, which will have the possible effect of reducing negative impact on humans/environment. Here, control is identified here as the effective use of waste available, as waste is considered as posing a threat to human health or environment. The manner in which it may be disposed off and partly because the holder no longer has the same sense of obligation in relation to it

Waste can come in different forms; it could be solid-metal, gaseous-chemical or liquid. Akaninyere \& Atser (2001) cited in Fakere, Fadairo \& Oriye (2012) examined the typology, characteristics and future trends of solid waste in selected Nigerian urban cities (including Ijebu-Ode) and asserted that the major components of waste are degradable materials (food remnants, paper, and rags) and non-biodegradable (plastics, tins, metals, bottles, glass, and bones). The finding was further buttressed by Fakere, Fadairo \& Oriye (2012) who submitted that most activities which affect the environment stem from the need for food; its production, processing and preparation. As such, some of the wastes are likely to have socio-economic potentials if effective urban mining mechanisms are designed. 


\section{Literature Review}

\section{The Waste Situation in Ogun State}

Waste generation is certainly a challenge in Ogun State as well as many other states in Nigeria. The challenge has continued unabated in spite of some very obvious steps taken by government in curtailing the problem posed by the waste generated by the citizens. A major challenge noticed in Ogun State according to Oloyede, Ayedun, Durodola \& Peter (2014) is that 'the solid waste challenge being encountered in Ota (Ogun State) presently stems from disparity between the rate of solid waste generation and the rate of collection and evacuation, thus leading to solid waste accumulation across the nooks and corners(sic) of the town'. Aside from the claims of Oloyede et al., (2011), Ochuko (2014) equally claimed that 'there are various problems facing Obantoko area of Abeokuta in South Western Nigeria. Among these numerous problems are inadequate water supply, bad road network and poor waste management. The most prominent among them that needs urgent attention is that of waste management'. This situation is common place across the Ogun State particularly the major towns and cities. The embarrassment this situation has caused the successive governments must have informed the Monthly Environmental Sanitation Exercise put in place by the State Government (Military and Civilian) in the last two decades or more.

The monthly exercise seems to have failed to address the problem as expected as the State will still qualify as a dirty State going by its inability to manage waste generated by individuals, households, groups and industries in the State. Corroborating this position, despite various efforts at enforcing environmental sanitation in Nigeria at both national, State and local government council levels and the benefits of these efforts in terms of providing employment, alleviating poverty, improving public health and sanitation as well as a reduction in environmental pollution, there is still the issue of continuous increase in uncollected residential solid waste (Oloyede et al., 2014). Failure of the efforts may be connected with the present attitude of seeing 'waste as waste' and not 'waste as wealth'. Fortunately, the very high level of unemployment has created opportunity for a gradual change in perception from 'waste as waste' to 'waste as wealth'. In fact, Oloyede et al., (2014) found out in Ogun State that: 'as a result of prolonged years of unemployment, many people had resorted to recyclable solid waste collection and sale of same for survival, encouraging the establishment of cooperative societies among the various groups of waste collectors, buyers and users'.

\section{Waste, Wealth and Entrepreneurship: The Urban Miners and Farmers Approach}

The study of entrepreneurship in contemporary times can be rooted in the works of Max Weber and Joseph Schumpeter as the reference points for the origin of the study of entrepreneurship and its role in the development process within modern economy. While Weber may be seen as a 'spiritualist' construction of modern economy
(Labinjoh, 1995), Schumpeter, on the other hand, can be described as the 'innovator' of modern economy. For him it is "the doing of new things or the doing of things that are already being done in a new way stemmed directly from the effort of entrepreneurs (Schumpeter, 2009). Entrepreneurs are innovators that are essentially needed in every society to help bring about desirable change in socio-economic conditions (Tillery and Young, 2009; Lennox and York, 2011). In doing this, they believe that entrepreneurs provide the innovation or "creative destruction" that gives society a new way of addressing problems. They also maintained that "environmental problems (i.e. waste) inherently calls for innovation, as most of them are caused by the out-dated applications of old, polluting, uncontrolled composition pattern and inefficient technology". Waste as a major environmental problem calls for entrepreneurial action to develop new methods of addressing the challenge posed on human and social development as a result of increasing volume of waste materials in the environment. However, within the context of entrepreneurial studies, researches have shown that waste is one of the viable resources or inputs used in production of consumable goods and services (Steffen, 2011; Jayathilakan, Sultana, Radhakrishna \& Bawa, 2012; Littlewood \& Holt, 2015). The utilization of waste in production of goods and services serves as means of encouraging entrepreneurial skill development (Littlewood \& Holt, 2015). Nowadays, the collection, separation and reproduction of waste have been a source of employment and wealth creation for individuals, organizations and governments across the globe. For example, empirical studies show that in countries like Switzerland, Germany, Australia, Japan, India and United Kingdom to mention but few, solid waste has been the most important resource used for generating energy and heat for running industrial plants and domestic electronic appliances (Berlin Senate Department for Urban Development and the Environment, (2013); Shariar \& A1 Bustam, (2012); Renewable Energy Association, (2012); Holmgren \& Henning, (2004). Similarly, reports from evidence-based studies revealed that the composting of food waste with certain species of earthworms as well as waste from fruits and vegetables are used as fertilizer to boost agricultural production and socio-economic conditions in Malaysia (Tan, 2015; Kapoor, J., Sachin S. \& Rana N K, 2015). The use of waste for fertilizer production is particularly common in developing countries however; there are more socio-economic potentials that can be derived from waste recycling such as employment generation which may impact directly poverty at micro level.

Furthermore, waste production creates employment opportunities for hundreds of thousands of poor people, youths and women who tapped into the business of collecting, sorting, sales and recycling of waste materials (Littlewood \& Holt, 2015). To corroborate this fact empirical researches carried out in Kenya, Mexico and Indonesia submitted that a reasonable amount of unemployed youths have become merchants in waste 
business and it is reported that they earn reasonable income from waste business- collection, mining and recycling (Velasco, 2011; Tatiana, 2010; Damanhuri \& Padmi, 2009). To further substantiate the nexus between waste, wealth and entrepreneurship development many organizations have also keyed into the business of waste recycling and management. For example, a number of corporate organizations were reported to have invested into carbon credits. The sale and purchase of carbon credits is one of the lucrative businesses in China, Japan, United States of America and Australia today (Gupta, 2011). Carbon credit is bought when a company emits more than one tonne of carbon dioxide or a corresponding amount of other greenhouse gases to the air. While on the other hand, when a company emits below expected quota can sell their remaining credits. In an investigation conducted by Simire (2011), Nigeria can also earn significant income from the business of carbon credits based on the fact that Pan Ocean Oil Gas Utilization Project generates about \$1.8 million worth of carbon credits annually (Simire, 2011). This is just one out of the numerous carbon producing companies operating in Nigeria.

Moreover, the unprecedented growth in research and development on waste recycling has contributed to the promotion of artisan-ship and handcraft activity among youths and women in rural and urban areas. Studies have documented various forms of products and crafts are produced from waste materials to include textile making, hand paper making, toys, jewellery, puppet, puzzles and games, wall decorations, files and folders etc. (Aggarwal, 2010; Artisan U.S. Mid-Cap Growth Strategy, 2016). These products have been confirmed to be very useful for domestic and industrial purposes with high quality and durability. They also have second value by being recyclable for production of new ones. Thus, waste utilization for economic and agricultural activities have added more value to entrepreneurship development in contemporary societies by encouraging the growth of eco-supportive inventions, initiatives (i.e. solar cars, energy and machines), and green businesses (i.e. waste mining, tree planting, green cleaning, mobile farming, eco-crafts and artisans) which do lead to sustainable development.

\section{Research Objectives and Justification}

As the general aim of the study is to examine waste generation, management and wealth creation in Ogun State, Nigeria, the paper specifically addresses the possibility of wealth creation beyond theoretical postulations, which abound from previous studies on waste in Nigeria. For example, Ndubisi-Okolo, Anekwe \& Attah (2016) wrote on Waste Management and sustainable development in Nigeria: a study of Anambra State Waste Management Agency; Ezibgo (2012) wrote on Management of Solid Waste in Nigeria: Challenges and Proposed Solutions; Egun (2012) also wrote on The Waste to Wealth Concept: Waste Market Operation in Delta State; Babayemi \& Dauda (2009) did their study on Evaluation of Solid Waste Generation, Categories and Disposal Options in Developing Countries: A Case study of Nigeria and Amori, Fatile, Ihuoma, \& Omoregbee, (2013) studied Waste Generation and Management Practices in Residential Areas of Nigerian Tertiary Institutions. None of the studies delved into actual process of turning waste to wealth for the purpose of creating wealth, which is what this study intend to achieve by throwing entrepreneurial challenge at the indigenous talented and skillful individuals beyond the theoretical postulations. Perhaps the only one close to the intention of this paper is the study by Sridhar \& Hammed (2014) that worked on 'Turning Waste to Wealth in Nigeria'.

The researchers' various projects at the University of Ibadan have brought out significant contributions on the waste to wealth initiatives. They have introduced source segregation in some eight pilot communities in Ibadan and Lagos where they were able to separate plastic/nylon, metal and organic fraction from the household wastes. They have fabricated necessary machinery locally (without any imported component) to recycle plastic/nylon, metal scrap and organic matter and established the facilities (with various production capacities) at the following locations:

\section{(i) Pace Setter Organo-mineral Fertilizer Plant}

A 10-ton per day capacity "Pace Setter Organo- mineral Fertilizer Plant" was designed and built for Bodija market in Ibadan (1998), Nigeria which is the first prototype demonstration project in the country. This has aroused interest all over the country and the Federal Government has recommended similar prototype for the entire country as a part of "Waste to Wealth Initiative" and as a strategy for "Poverty Alleviation" and Sustainable Development. Based on this, UNDP and UNCHS have engaged expertise in propagating this technology to 36 States in the country through Workshops. University of Ibadan, Sustainable Ibadan Project and Ibadan Waste Management Authority have bagged National and International Merit Awards and appreciation. The Technology is available under the Team "Environmental Development Foundation".

\section{(ii) Organo-Mineral Fertilizer Plant}

A 5-ton per day capacity organo-mineral fertilizer plant was designed and built for Ayeye community, Ibadan (2002) where sorting of non-biodegradable and biodegradables were practiced; recyclables and the organo-mineral fertilizer are being sold.

\section{(iii) Food Residual Conversion to Compost}

A 5-ton per day capacity food residual conversion to compost (2002) was developed for a flow station at Shell Petroleum Development Company, Forcados, Delta Sate; Turning Waste to Wealth in Nigeria 2001 the compost produced is being used for maintaining their lawns and gardens.

\section{(iv) Pace Setter Integrated Waste Management Complex}

A 10- ton per day capacity "Pace Setter Integrated Waste Management Complex" was designed and built 
(2005) for Oyo State Government at Orita-Aperin, Ibadan where an organo-mineral fertilizer plant, a plastic recycling plant and a scrap metal recycling plant were designed and built for management of Solid waste generated in Ibadan.

Thus attempt is herein made to combine the existing ideas on waste across the academia and relate it to actual practice to generate new products, develop skills, and generate employment and wealth in the context of Ogun State and Nigeria.

\section{Methods and Data}

As a case study research, a combined descriptive and exploratory research design was adopted and the social constructionist qualitative orientation was utilized. Following a tool development discussion process with stakeholders in the academia and industry, two (2) wasteentrepreneurs were purposively selected for the study. This is based on the focus of the study, on actual process of wealth creation from the vast heaps of waste in Ogun State, Nigeria, beyond theoretical postulations. Being a qualitative research, interviews and observations were recorded. Interviews were transcribed and thematically analysed through a manual procedure. Also, images were analysed based on the themes and pattern of process in the discussion. The study outcome is captured with consideration of research location, study population and tool structure.

\section{Findings and Discussions}

\section{The Process-Outcome of Specific Wastes}

1. Transforming Corn/Maize Husk into Husk Paper Product

Nigeria as a nation is still highly agrarian in its economic outlook in spite of its heavy dependence on oil for her revenue. Yet her full potentials in agriculture are yet to be tapped into especially the waste generated from agric related activities. She has suffered from heavy deforestation in order to meet some basic needs that draw input from trees from the forest. She relies on paper products daily for her various private and public tasks because she is yet to migrate sufficiently into electronic transactions with reduced paper needs. Most of the paper products are the outcomes of heavy deforestation to be manufactured from raw trees from the forest. The effect of this is heavy deforestation.

The husk paper product as we have found out from this study is an alternative aimed at reducing deforestation and improving the health of the Nigerian environment by producing paper products both for household and offices that are eco-friendly especially believers in LOHAS i.e Lifestyle of Health and Sustainability.

You will no longer have to rely on paper products made from trees. Husk Paper Products is proud to present household paper products made from a unique material: corn husks and stalks. Made using the same processes as paper products produced from trees, paper from corn waste is equally functional to current tree-based paper, without the detrimental effects to forests. Husk Paper Products provide an environmentally friendly alternative to help reduce heavy deforestation.

The corn waste was pulped before it was transformed in to paper products. It was pulped using the hand process to convert the corn waste into pulp. After the corn waste has been pulped, it was sent to a paper mesh to be shaped, pressed, and dried into size of paper required. Husk Paper Products, which is primarily, corn waste is usually disposed of by being burned in the fields, which causes $\mathrm{CO}^{2}$ and smog emissions that are known to be health and traffic hazards. The use of the corn waste therefore will reduce the $\mathrm{CO}^{2}$ and smog emissions from this method of disposal.

\section{Transforming Sachet Water Nylon into Pave Stones/Slabs}

Bunmi Sunmola, one of the indigenous Entrepreneurs invited to the workshop on waste to wealth came up with the Step-by-step process of producing Pave stones from sachet water nylon often thrown into drainages in Nigeria. The process is as follows:

Melting the mixture - Plastic is melted in a simple drum, often made from readily available oil drums, or thicker sheet metal that is specially welded together. It is vital that those involved in the melting process wear adequate safety equipment, including eye protection, breathing apparatus, gloves, overalls and safety boots. When all the plastic in the drum is melted into a thin liquid, it is ready to be mixed. Mixing - Sand is then added and mixed with specially created mixing poles, until a smooth consistency is formed. The mixture must be kept moving to avoid burning. Moulding - The mixture is then poured into metal moulds on a metal table, which are all greased with engine oil to prevent sticking. The mixture is compacted and smoothed using large trowels and a hand operated compactor, and the finished product is removed from the mould. Drying - Completed products are placed in the sun to dry for up to 24 hours, after which they are ready to be used.

\section{Transforming Banana Stem, Sisalina Leaves and Pineapple Leaves into Weaving and Matting fibre}

Mr Sunmola extracted natural fibre from Banana Stem, Agave Agustofoli (Sisalina Leaves) and Pineapple Leaves.

The plant sections were cut and then scrapped lightly to remove the excess moisture. Impurities in the scrapped fibres such as pigments, broken fibres, coating of cellulose etc. were removed manually, and then the fibres were cleaned and dried. This mechanical and manual extraction of fibres was tedious, time consuming, and caused occasional damage to the fibre. It is therefore not a technique that can be recommended for industrial application. A special machine was however discovered that could help in the industrial application. It is already 
designed and developed for the extraction of all kinds of fibres in a mechanically automated manner. It consisted mainly of two horizontal beams whereby a carriage with an attached and specially designed comb, could move back and forth. The fibre extraction using this technique could be performed simply by placing a cleaned part of the banana stem or leaves on the fixed platform of the machine, and clamped at the ends by jaws. This eliminated relative movement of the stem/ leaves and avoided premature breakage of the fibres (See the attached machine in Appendix 1).

\section{Transforming Arecanut Leaves/Palm into disposable plates and spoons}

The production of the disposable plates and spoons from areca leaves is about the simplest, easiest and fastest waste to wealth production process. It is a 'waste' completed to be wealth product by Nature. Areca leaf plates are perfect alternative to Plastics/Polymer based products. The product transformation from raw stage to finish stage is a $100 \%$ natural mechanism, where fallen areca leaves are collected from farms. The Sheath of the areca leaf cleaned and soaked in water for approximately 15 minutes and place the leaf in hydraulic dying machine (heater dying) for 30 to 40 secs to get proper finished plates. They are then compressed to different shapes using the correspondingly shaped Machines. They are then packed as per the customer requirement. Advantages of Arecanut Leaves/Palm include:

1. Eco-friendly, Bio-degradable and Compostable.

2. No chop down of trees, fallen leaves are collected and turned to value added products.

3. No Chemicals, bleaching, PE (Poly Ethylene) coating, Wax coating at any stage.

4. Light weight, sturdy and non-crushable.

5. Microwave \& Refrigerator safe.

6. Holds liquid items for 4 hours without leakage.

7. Good for hot, wet and cool food items.

8. It's disposable and can be used at any occasion like parties, buffets, picnics, outdoor catering, functions, food-joint and bukas in major cities across Nigeria.

9. It has a market potential of both local and international patronage. Each Areca leaf plate manufacturing unit can provides direct employment to 3 persons and there is an indirect impact of creating employment for 2 other persons.

\section{Conclusion}

Waste management in Nigeria is mostly construed as a public policy problem which is a major source of public health challenges. The research has however documented proven processes which ensure the possibility of wealth creation through specific wastes. As Nigeria contends with the vast array of wastes, the study identifies the fact that corn/maize husk provides a good source of paper production. The study identifies the economic and environmental benefit that such utilization process encourages. In examining the production process of paving stones through pure water nylons (which are in large deposits across cities in Nigeria), the study emerged with a frame work for the manufacturing of building materials. Due to the ubiquitous nature of pure water nylons, it has emerged with equally large productive ends at minimal cost for business start-ups. Also, the process of transforming Banana stem, Sisalina leaves and Pineapple leaves into fibres suitable for producing mats and other fibre related purposes was examined. Although the production process can occur within small-scale business structures, it was identified as a technologically-demanding and capital intensive venture, because the process of fibre extraction requires significant effort. In the use of Arecanut leaves/palms as parent material for the production of disposable spoons and plates, the study identified the process of deriving such utensils and the potentials that it assures. Its potentials in terms of cost effectiveness and employment are significant. It is important that local and foreign investors understand the business opportunities and government also provides an enabling environment for business investments and funding. This is good for young entrepreneurs who are readily interested in harnessing the wastes potential in Nigeria. The policy environment should also be enabling for local production and consumption of the products that are developed through this process.

\section{Acknowledgment}

The research team acknowledges the funding received from the TETFund Institution Based Research (TETfund IBR). The research team also recognizes the committee on Research and Learned Conferences at Olabisi Onabanjo University, Ago-Iwoye, Ogun State Nigeria, for the institutional support received in the course of the research.

\section{Appendix 1}

Fibre Extractor For Banana, Pineaple and Sisalina Leaves

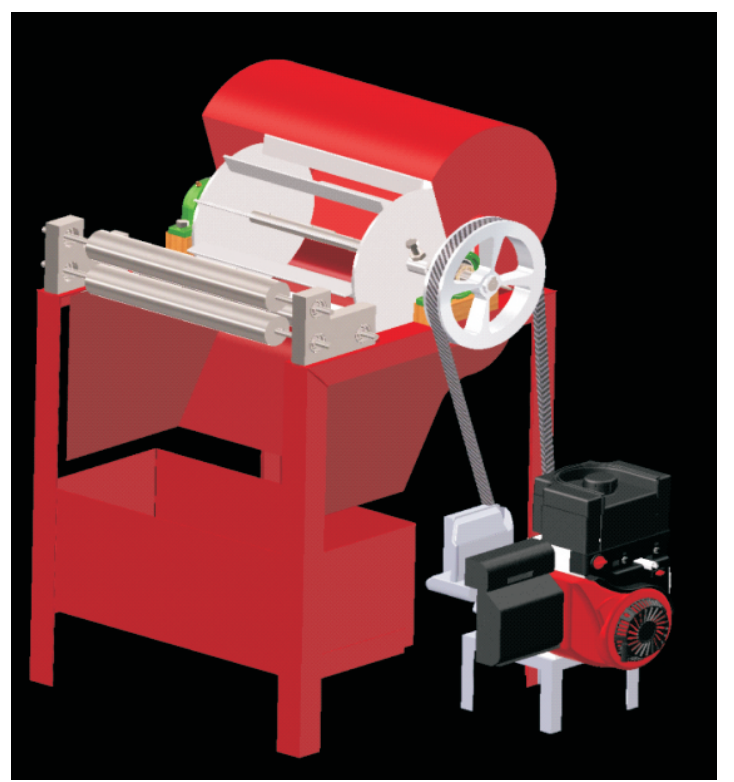

DRAWN, Production \& Manufacture: Eng. Malema H. Malema https://www.grabcad.com 


\section{References}

Abati, B. 2013. Waste-To-Wealth Potentials of Municipal Solid Waste: The Case of GA-East Municipal Assembly, Ghana. M.Sc Project Report Presented to Faculty of the Graduate School of Asia Pacific Studies, Ritsumeikan Asia Pacific University.

Achi H. A., Adeofun C. O., Ufoegbune G. C., Gbadebo A. M. \& Oyedepo J. A. 2012. Disposal Sites and Transport Route Selection Using Geographic Information System and Remote Sensing in Abeokuta, Nigeria. Global Journal of Human Social Science, Geography \& Environmental GeoSciences. Volume 12 Issue 12 Version.

Ajzen I. 1991. The theory of planned behavior. Organizational Behavior and Human Decision Processes, 50, p. 179-211.

Adeyemi, B. O 2011. Waste Management in Contemporary Nigeria: The Abuja Example. International Journal of Politics and Good Governance. Vol. 2 No. 2(2). Pp. 1-18.

Adewole A. T. 2009. Waste management towards sustainable development in Nigeria: A case study of Lagos state. International NGO Journal. Vol. 4 (4), pp. 173-179.

Adesiyan S. O. 2005. Man and his Biological Environment. Ibadan University Press, Nigeria.

Akanni C. O. 2010. Spatial and Seasonal Analyses of Traffic-related Pollutant Concentrations in Lagos Metropolis, Nigeria. Africa Journal of Agricultural Research Vol. 5 (11).

Akaninyere. M. \& Atser. J. 2001. Solid Waste Characterization and Management Issues In Uyo Municipalities, Nigeria. Libro-Gem, Lagos, Nigeria.

Akinola. S. \& Salami. R. 2001. An Assessment Of The effectiveness of Private Sector Participation Initiatives In Solid Waste Management in Mushin Local Government Area, Lagos State. Nigerian Journal of Social And Educational Research. A Publication of the Nigerian Association of Social and Educational Research, University of Ado-Ekiti.

Amori, Fatile, Ihuoma, \& Omoregbee, 2013: Waste Generation and Management Practices in Residential Areas of Nigerian Tertiary Institutions Journal of Educational and Social Research Vol. 3 (4) ISSN 2239-978X.

Ayoola P. B, Adekeye E. A \& Jakanola O. O. 2012. Environmental Pollution and Control within Sabo Area of Ogbomoso in Oyo State of Nigeria. IJRRAS $10(2): 329-338$.

Aggarwal, R. (2010). Recycle and reuse of textiles. Retrieved August 19, 2017, from http://www.technopreneur.net/informationdesk/sciencetechmagazine

Artisan U. S. Mid-Cap Growth Strategy (2016). Quarterly Fact sheet. Available online at http://www.artisanpartnersglobal.com/docs/USMi dCapGrowth-Fact-Sheet-4Q16-vXUS.pdf

Babayemi, J. O \& Dauda, K. T 2009: Evaluation of Solid Waste Generation, Categories and Disposal Options in Developing Countries: A Case study of Nigeria,
Journal of Applied Science and Management JASEM 1119-8362 Vol. 13(3).

Berlin Senate Department for Urban Development and the Environment (2013) No Regrets: Circles of Climate Change Adaptation: Principles and Practices for Responding to Climate Change. Available online at: http://www.circlesofclimate.org/about/aboutus/berlin-senate-department-for-urban-developmentand-the-environment

Chukwuemeka, E. E. O. Osisioma, B. C. Onwuka, E. \& Ugwu, J. 2012. The challenges of waste management to Nigeria sustainable development: A study of Enugu State. International Journal of Research Studies in Management. Vol. 1 (2), 79-87.

Damanhuri, E. \& T. Padmi (2009), 'Current Situation of Waste Recycling in Indonesia', in Kojima, M. and E. Damanhuri (eds.), 3R Policies for Southeast and East Asia. ERIA Research Project Report 2008-6-1, pp.2352. Jakarta: ERIA.

De Cuba, K., Burgos, F., Contreras-Lisperguer, R. and Penny, R. 2010 Limits and Potential of Waste-ToEnergy Systems in the Caribbean. Department of Sustainable Development. Organization of American $\mathrm{S} t \mathrm{at}$ e s. $\quad \mathrm{R}$ e $\mathrm{t} \mathrm{r}$ i e $\mathrm{ved} \quad \mathrm{f} \mathrm{r}$ o $\mathrm{m}$ http://www.oas.org/dsd/reia/Documents/Limitsa ndPotentialofWastetoEnergy.pdf on December 05, 2015.

Egun, N. K 2012: The Waste to Wealth Concept: Waste Market Operation in Delta State Green Journal of Social Sciences. Vol 2, No 6 ISSN 2276-7800.

EIONET. 2009. Waste. Retrieved from http://scp.eionet.europa.eu/definitions/waste on October, 2012.

Ezibgo, C. A 2012: Management of Solid Waste in Nigeria: Challenges and Proposed Solutions. Sacha Journal of Environmental Studies, Vol 2:1.

Fakere, A. A., Fadairo, G \& Oriye, O. 2012. Domestic Waste Management and Urban Residential Environment: Focus on Akure, Nigeria. International Journal of Engineering and Technology Vol. 2 No. 5 pp: 878-887.

FEPA 1998 (Federal Environmental Protection Agency). National Policy on the Environment. Nigeria: FEPA, P. 22.

Fobil, J. N., Carboo, D. \& Armah, N. A. 2005. Evaluation of Municipal Solid Wastes (MSW) for Utilisation in Energy Production in Developing Countries. International Journal of Environmental Technology and Management, Vo1. 5 (1), pp. 76-86. doi:10.1504/IJETM.2005.006508.

Guti B., Aji M. M. \& Magaji G. 2012. Environmental impact of natural resources exploitation in Nigeria and the way forward. Journal of Applied technology in Environmental Sanitation. Vol. 2: 2 pp: 95-102.

Gupta, Y. (2011) Carbon Credit: A Step towards Green Environment. Global Journal of Management and Business Research Vol. 11 (5): 16-19.

Jegede M. O. 1977. Waste Disposal Habits of Some 
Industries in Ikeja Industrial Estate, M.Sc Project Report Chemistry Department, University of Ibadan.

Hogland, W., Hogland, M. \& Marques, M. 2015. Enhanced Landfill Mining: Material Recovery, Energy Utilisation And Economics In The EU (Directive) Perspective. Asian Regional Research Programme on Environmental Technology, Bangkok.

Holmgren, K., \& Henning, D., (2004). Comparison between material and energy recovery of municipal waste from an energy perspective: a study of two Swedish municipalities. Resources, Conservation and Recycling 43, 51-73. http://dx.doi.org/10.1016/j.resconrec

Kapoor, J., Sachin S. \& Rana N. K. (2015) Vermicomposting For Organic Waste Management. International Journal of Recent Scientific Research. Vol. 6 (12): 7956-7960.

Kan H. 2009. Environment and Health in China: Challenges and Opportunities Environmental Health Perspectives, 117(12), pp. A530-A531.

Labinjoh, J. (1995). Max Weber, the Protestant Ethic and Development, Ibadan Sociology Series No. 2. Department of Sociology,, Nigeria.: University of Ibadan.

Lennox, M., \& York, J. G. (2011). Environmental entrepreneurship. In A. J. Hoffman \& T. Bansal (Eds.), Oxford handbook of business and the environment, Oxford, UK: Oxford University Press.

Littlewood, D \& Holt, D (2015) Social Entrepreneurship in South Africa. Exploring the Influence of Environment. Business and Society. 1-37.

Jayathilakan, K., Sultana, K., Radhakrishna, K. \& Bawa, A. S. (2012) Utilization of By products and Waste Materials from Meat, Poultry and Fish Processing Industries: A Review. Journal of Food Science and Technology, 49, 278-293.

Ndubisi-Okolo, P. U, Anekwe R. I \& Attah E. Y 2016: Waste management and sustainable development in Nigeria: a study of Anambra State Waste Management Agency, European Journal of Business and Management. Vol: 8, No. 17.

Ministry for the Environment, Nature Conservation and Nuclear Safety (MENCNS) (Sept., 2010). General Information Waste Management i $\mathrm{n} \quad \mathrm{G}$ e r m a n y. Re t ri e ved fro m http://www.bmu.de/english/waste management/g eneral information/doc/4304.php 2011.

Murray, R. (1999). Creating Wealth from Waste. Demos Panton House London, U.K.

Ogedengbe, P. S \& Oyedele, J. B. (2006). Effect of waste management on Property values in Ibadan, Nigeria. Journal of land use and development studies, Vol 2, No 1.
Ogwueleka T. Ch, 2009. Municipal solid waste characteristics and management in Nigeria. Iran. J. Environ. Health. Sci. Eng., Vol. 6, No. 3, pp. 173-180.

Renewable Energy Association and Renewable UK meetings (2012): FOI request 12/0968. A va i $1 \mathrm{able}$ o n $1 \mathrm{ine}$ a t : https://www.gov.uk/government/publications/rene wable-energy-association-and-renewable-ukmeetings-foi-request-12-0968

Sahara Reporter. 2011 . available at http://saharareporters.com/2011/10/24/problemnigeria-you-and-me Retrieved on 25 th December, 2014.

Solaja O. M., Omobowale O. A \& Kalejaiye P. O. 2014. Sociological Investigation of Industrialization and Environemntal Pollution in Lagos Metropolis. AgoIwoye Journal of Social and Behavioural Sciences. Vol. 3(1) pp: 220.

Schumpeter, Joseph A. (1948, 2009). "There is still time to Stop Inflation" in Schumpeter, Joseph A. (author); Clemence, Richard V. (editor), Essays: On Entrepreneurs, Innovations, Business Cycles and the Evolution of Capitalism, Nation's Business 1,. New Brunswick, New Jersey: Transaction Books, pp 241252 ISBN 978141822749.

Sridhar M. K. C \& Hammed, T. B 2014: 'Turning Waste to Wealth in Nigeria: An Overview' Kamal Raj 46(2): 195-203.

Shariar, F., K \& Al Bustam, H (2012) Waste to Energy: A New Dimension in Generating Electricity in Bangladesh. IACSIT International Journal of Engineering and Technology, Vol. 4(4): 480-483.

Simire, M. (2011). A fresh, green colour for business. Daily I $n$ d e pe nde $n t$. Re trie ved f r o m https://greennigeria.wordpress.com on January $3^{\text {s, }}$, 2017.

Steffen, L. (2011) Optimizing Urban Material Flows and Waste Streams in Urban Development through Principles of Zero Waste and Sustainable Consumption. Sustainability, 3, 155-183.

Tan, L. M (2015) Production of Fertilizer using Food Wastes of Vegetables and Fruits. B.Sc Dissertation submitted to Department of Plant Science and Environmental Ecology Faculty of Resource Science and Technology University Malaysia Sarawak.

Tillery, F., \& Young, F. (2009). Sustainability entrepreneurs: Can they be the true wealth generators of the future. Greener Management International, 55, 79-92.

Velasco, P. A. G. M. (2011). Generation and disposition of MSW in Mexico and Potential for improving Waste Management In Toluca Municipality. M. S. Dissertation submitted to Department of Earth and Environmental Engineering, Columbia University. 